\title{
Celiac disease associated with aplastic anemia in a 6-year-old girl: a case report and review of the literature
}

\author{
Omar Irfan', Sana Mahmood ${ }^{1 *}$, Heera Nand² and Gaffar Billoo²
}

\begin{abstract}
Background: Celiac disease may present with hematological abnormalities including long-standing anemia. Both aplastic anemia and celiac disease have a similar underlying autoimmune process but an association between the two is seldom reported. There have only been three pediatric cases reporting this association and this case is the first reported in a female pediatric patient.

Case presentation: We report a case of 6-year-old South Asian girl presenting with bruises, petechiae, and recent history of loose stools. On evaluation, she was diagnosed as having celiac disease and was put on a gluten-free diet and further investigations including bone marrow biopsy revealed pancytopenia. She was managed with packed red cells, platelets, and diet restrictions and had improving platelet counts over yearly follow ups. Her parents were counseled regarding the need for bone marrow transplant.

Conclusions: This is the fourth case report suggesting an association between celiac disease and aplastic anemia in the pediatric population and this association could be more common than expected. Timely intervention of either celiac disease through strict gluten-free diet or aplastic anemia through immunosuppressive therapy could potentially reduce the risk for other autoimmune conditions. We can see that all four pediatric cases reported with this potential association are from South East Asia and hence larger studies would be prudent to explore this association.
\end{abstract}

Keywords: Aplastic anemia, Celiac disease, Gluten-free diet, Child, Bone transplant

\section{Background}

Celiac disease $(\mathrm{CD})$ is an autoimmune disease characterized by reversible small bowel mucosal inflammation with villous atrophy causing malabsorption [1]. It causes malabsorption of iron, folic acid, and/or vitamin B12, with additional features of anemia of chronic disease [2]. Many hematological manifestations, mostly due to nutritional deficiencies, have been associated with $\mathrm{CD}$ [2]; however, the occurrence of aplastic anemia (AA) is extremely rare. There is a known association between $\mathrm{CD}$ and AA as both have a similar pathological process involving autoreactive $\mathrm{T}$ cell destruction of tissue [3]. Both diseases share an underlying immune mechanism as the human leukocyte antigen (HLA) DQ2 allele is identified in 90 to $95 \%$ of celiac individuals, and HLA

\footnotetext{
* Correspondence: sana-mahmood@hotmail.com

${ }^{1}$ Medical College, Aga Khan University Hospital, Karachi, Pakistan

Full list of author information is available at the end of the article
}

DQ8 in the rest [1]. The cumulative risk for development of various autoimmune diseases is $8.1 \%$ at 15 years of age in patients with CD [4]. Previously, there have been three reported pediatric cases of AA in association with $\mathrm{CD}$ as compared to more data for adults [5]. We report the case of a 6-year-old girl with $\mathrm{CD}$ and $\mathrm{AA}$ causing bone marrow failure. This is the fourth report in the literature to date that suggests an association of AA with $C D$ in the pediatric population.

\section{Case presentation}

A 6-year-old South Asian girl presented in October 2013 with generalized bruises, undocumented fever, and eczematous rashes of 1 month's duration. She had had six or seven episodes of loose stools per day for 3 months accompanied by loss of appetite. She was a known asthmatic. Her family history was unknown as she was an adopted child. Her foster parents did not notice any food allergens. On examination, she was short with a height 
of $98 \mathrm{~cm}(<5$ th percentile) and weight of $13.5 \mathrm{~kg}(<5$ th percentile). There was pallor, multiple generalized petechiae, and eczematous patches on upper back and behind her ears with typical Fanconi facies including microcephaly and microphthalmia. A systemic examination was normal and no lymphadenopathy was appreciated.

Investigations revealed hemoglobin of $9.0 \mathrm{~g} / \mathrm{dl}$, platelet count of $67 \times 10^{9} / \mathrm{L}$, and mean corpuscular volume (MCV) and mean corpuscular hemoglobin $(\mathrm{MCH})$ of $75.3 \mathrm{fl}$ and $24.2 \mathrm{pg}$, respectively with no atypical cells. A liver function test (LFT), renal function test (RFT), urine examination, and coagulation profile were normal and blood culture was sterile. Ultrasonography of her abdomen and portal venous Doppler were normal. Antinuclear antibodies (ANA) titer was negative. Mitomycin $\mathrm{C}$ was used to detect chromosomal breakages to rule out Fanconi anemia and results were negative with 0.58 breaks/cell. Investigations for malabsorption revealed gamma A immunoglobulin (IgA) tissue transglutaminase levels to be $370 \mathrm{IU} / \mathrm{ml}$ (normal < $12 \mathrm{IU} / \mathrm{ml}$ ), anti-gliadin antibodies to be $140 \mathrm{IU} / \mathrm{ml}$ (normal $<12 \mathrm{IU} / \mathrm{ml}$ ), but normal thyroid profile. A jejunal biopsy showed complete villous atrophy with increased intraepithelial lymphocytes consistent with diagnosis of $\mathrm{CD}$. She was managed with antibiotics, packed red cells, and platelet support and was put on a gluten-free diet. She was supplemented with multivitamins, vitamin $C$, and iron. She was discharged on day 17 of hospital stay with hemoglobin of $7.9 \mathrm{~g} / \mathrm{l}$, total leukocyte count of $2.5 \times 10^{9} / \mathrm{l}$, and platelet count of $46 \times 10^{9} / \mathrm{l}$. A bone marrow biopsy was advised. The household was noncompliant to follow ups with yearly follow ups showing varying platelet levels from $34 \times 10^{9} / \mathrm{L}$ to $124 \times$ $10^{9} / \mathrm{L}$

The child presented in October 2016 with nonproductive cough, fever, respiratory distress for 2 months, and a history of recurrent infections over the past year. Her hemoglobin was $7.5 \mathrm{~g} / \mathrm{l}$, total leukocyte count of $3.5 \times 10^{9} / \mathrm{l}$, and platelet count of $80 \times 10^{9} /$ l. High-resolution computed tomography (HRCT) was suggestive of a lung abscess. Lung culture revealed Pseudomonas aeruginosa. GeneXpert, galactomannan, and $\beta$-D-glucan (BDG) antibodies were negative. She was managed symptomatically with blood transfusions and platelet support. A bone marrow trephine biopsy was done after consent that revealed hypocellular bone marrow with decreased lymphoid cells, plasma cells, erythroid and myeloid precursors with occasional megakaryocytes. We advised that the child have a bone marrow transplantation but the family refused due to financial constraints. The parents were counseled about the nature of the disease and treatment modalities. She is managed with packed red cells, platelet support, and a gluten-free diet; she showed an increasing trend in platelet count on last follow up.

Table 1 shows a timeline for our patient's past medical history and follow-up visits as well as interventions.

Table 1 Timeline of patient's medical history

\begin{tabular}{|c|c|c|c|}
\hline & \multicolumn{3}{|l|}{ Past medical history } \\
\hline & \multicolumn{3}{|c|}{$\begin{array}{l}\text { A 6-year-old girl with history of bruising and fever for } 1 \text { month and loose stools for } 3 \text { months. She was a known asthmatic. Her family history } \\
\text { was unknown as she was an adopted child. }\end{array}$} \\
\hline & Hospital/out-patient visits & Diagnostic tests & Interventions \\
\hline \multirow[t]{2}{*}{$\begin{array}{l}\text { October } \\
2013\end{array}$} & $\begin{array}{l}\text { Presented with bruises, undocumented fever, } \\
\text { and eczematous rashes for } 1 \text { month. Petechiae } \\
\text { all over the body. Loose stools daily for } 3 \text { months } \\
\text { with loss of appetite. }\end{array}$ & $\begin{array}{l}\mathrm{Hb} 9.0 \mathrm{~g} / \mathrm{dl} \text {, } \\
\text { platelet } 67 \times 10^{9} / \mathrm{L} \text {, } \\
\text { MCV } 75.3 \mathrm{fl}, \\
\text { MCH } 24.2 \mathrm{pg} \text {. } \\
\text { Normal LFT, RFT, urine examination, and } \\
\text { coagulation profile. Blood culture was sterile. } \\
\text { ANA titer was negative. } \\
\text { Chromosomal breakages was negative with } \\
0.58 \text { breaks/cell, } \\
\text { IgA tTG } 370 \mathrm{IU} / \mathrm{ml} \text {, } \\
\text { anti-gliadin antibodies } 140 \mathrm{IU} / \mathrm{ml} \text {. } \\
\text { Jejunal biopsy - complete villous atrophy with } \\
\text { increased intraepithelial lymphocytes. }\end{array}$ & $\begin{array}{l}\text { Antibiotics, packed red cells, } \\
\text { and platelet support given. } \\
\text { Put on a gluten-free diet, } \\
\text { supplemented with multivitamins, } \\
\text { vitamin } \mathrm{C} \text {, and iron. } \\
\text { She was discharged on day } 17 \text { of } \\
\text { hospital stay with } \mathrm{Hb} 7.9 \mathrm{~g} / \mathrm{l} \text {, } \\
\text { TLC } 2.5 \times 10^{9} / \mathrm{l} \text {, } \\
\text { platelet count of } 46 \times 10^{9} / \mathrm{l} \text {, } \\
\text { and gluten-free diet. Bone marrow } \\
\text { biopsy was advised. }\end{array}$ \\
\hline & Noncompliant with yearly follow ups. & Varying platelet levels from $34 \times 10^{9} / \mathrm{L}$ to $124 \times 10^{9} / \mathrm{L}$. & Gluten-free diet \\
\hline $\begin{array}{l}\text { October } \\
2016\end{array}$ & $\begin{array}{l}\text { Nonproductive cough, fever, respiratory distress } \\
\text { for } 2 \text { months. } \\
\text { History of recurrent infections over the year }\end{array}$ & $\begin{array}{l}\text { Lung abscess and a cavitary lesion seen on HRCT. } \\
\text { Lung culture revealed Pseudomonas aeruginosa. } \\
\text { GeneXpert, galactomannan, and BDG } \\
\text { antibodies were negative. A bone marrow trephine } \\
\text { biopsy revealed hypocellular bone marrow. }\end{array}$ & $\begin{array}{l}\text { She is planned for bone marrow } \\
\text { transplantation. } \\
\text { Parents were counseled about the } \\
\text { disease and treatment. } \\
\text { Managed with packed red cells, } \\
\text { platelet support, and a gluten-free } \\
\text { diet. She showed an increasing } \\
\text { trend in platelet count. }\end{array}$ \\
\hline
\end{tabular}

ANA antinuclear antibodies, BDG $\beta$-D-glucan, $H b$ hemoglobin, HRCT high-resolution computed tomography, LFT liver function test $M C H$ mean corpuscular hemoglobin, MCV mean corpuscular volume, RFT renal function test, $T L C$ total leukocyte count, $T T G$ tissue transglutaminase 


\section{Discussion}

CD usually presents with long-standing anemia that may [3] be the only presenting symptom. Other hematological abnormalities include thrombocytosis, leukopenia, thromboembolism, and increased bleeding tendency. There may also be IgA deficiency, hyposplenism, and lymphoma. However, an association between $\mathrm{CD}$ and AA is seldom reported [6]. CD should always be considered in patients with hematological abnormalities even without any gastrointestinal manifestations (atypical CD). Diarrhea as a reported symptom is less frequent than before [7].

Table 2 compares the studies done on the CD-AA association.

A total of 11 cases with CD-AA association have been reported in the literature, out of which three are pediatric cases. In two of these three pediatric cases, both diseases were diagnosed simultaneously but in the third patient the diagnosis of AA is unconfirmed as no bone marrow biopsy was performed $[8,9]$. The most recent case developed AA after a previous diagnosis of CD [5]. There have been eight adult cases reported out of which five were diagnosed with $\mathrm{CD}$ and AA simultaneously and three had CD previously [5]. The adult ages ranged from 23 to 47 years while the pediatric cases ranged from ages 9 to 13 years. All the adults were female while all the pediatric cases were male. We report the fourth case in the pediatric population and the first female pediatric patient with a CD-AA association. All four pediatric cases reported, including ours, are from India or Pakistan.

The mechanism of cause and effect regarding this is unclear. CD is an autoimmune condition that involves gluten exposure and it affects multiple organs like the bone marrow. Micronutrient deficiencies like iron, folic acid, and others, which occur due to malabsorption, may lead to the bone marrow hypoplasia. Hence, a gluten-free diet, micronutrient supplementation, and immunosuppressive techniques like glucocorticoids have a possible beneficial effect on bone marrow function. This is useful for patients from a lower socioeconomic class who find it difficult to afford bone marrow transplants or antithymocyte globulin therapy [10].

All adult patients in a case series by Grey-Davies et al. were symptom-free from a gastrointestinal standpoint while adhering to a gluten-free diet [3]. A gluten-free diet decreases the exposure to antigenic stimuli that lead to bone marrow suppression and reverts the process [8]. Our patient was put on a gluten-free diet but due to infrequent follow ups it is difficult to comment on her dietary adherence. Timely immunosuppressive therapy for AA would also regulate development of other autoimmune diseases like CD [3]. There is a report of stabilization of CD in a pediatric patient after allogeneic hematopoietic stem cell transplantation [11] which further strengthens our decision to advise transplantation. It is likely that bone marrow transplant would improve her prognosis.

\section{Conclusions}

This is the fourth case report suggesting an association between $\mathrm{CD}$ and $\mathrm{AA}$ in children making it probable that an association between these two entities might be more common than expected. It is still debatable whether there should be a call for routine immunological testing for tissue transglutaminase antibodies in patients with AA. There is a need for studies focusing on this association since it has been a nonentity until recently [8]. All four pediatric cases regarding the $\mathrm{CD}-\mathrm{AA}$ association have

Table 2 Comparison of all studies on patients with aplastic anemia and celiac disease

\begin{tabular}{|c|c|c|c|c|c|c|}
\hline Study & $\begin{array}{l}\text { Grey-Davies and } \\
\text { colleagues [3] }\end{array}$ & $\begin{array}{l}\text { Salmeron and } \\
\text { colleagues [12] }\end{array}$ & $\begin{array}{l}\text { Maheshwari and } \\
\text { colleagues [8] }\end{array}$ & $\begin{array}{l}\text { Kumar and } \\
\text { colleagues [9] }\end{array}$ & Badyal and colleagues [5] & Present study 2017 \\
\hline No. of cases & 3 & 5 & 1 & 1 & 1 & 1 \\
\hline Age (years) & $47,37,23$ & NA & 13 & 10 & 9 & 6 \\
\hline Gender & All female & NA & Male & Male & Male & Female \\
\hline Country & England & England & India & India & India & Pakistan \\
\hline Infection & $\begin{array}{l}\text { One patient had } \\
\text { Aspergillus and } \\
\text { Pseudomonas infection } \\
\text { and died }\end{array}$ & NA & $\begin{array}{l}\text { No history } \\
\text { of infection } \\
\text { present }\end{array}$ & $\begin{array}{l}\text { No history } \\
\text { of infection } \\
\text { present }\end{array}$ & $\begin{array}{l}\text { No history of infection } \\
\text { present }\end{array}$ & $\begin{array}{l}\text { Had infection with } \\
\text { Pseudomonas recently } \\
\text { with a history of } \\
\text { infections. }\end{array}$ \\
\hline $\begin{array}{l}\text { Small intestinal } \\
\text { biopsy }\end{array}$ & $\begin{array}{l}\text { Partial, subtotal, } \\
\text { and total villous atrophy }\end{array}$ & $\begin{array}{l}\text { Subtotal } \\
\text { villous atrophy }\end{array}$ & $\begin{array}{l}\text { Total villous } \\
\text { atrophy }\end{array}$ & $\begin{array}{l}\text { Subtotal } \\
\text { villous } \\
\text { atrophy }\end{array}$ & $\begin{array}{l}\text { Biopsy not done because } \\
\text { of active Gl bleed and low } \\
\text { platelet counts }\end{array}$ & $\begin{array}{l}\text { Total villous atrophy with } \\
\text { increased intraepithelial } \\
\text { lymphocytes }\end{array}$ \\
\hline lgA-tTG levels & Not mentioned & NA & $>205 \mathrm{IU} / \mathrm{mL}$ & $100 \mathrm{IU} / \mathrm{mL}$ & $>105 \mathrm{IU} / \mathrm{mL}$ & $370 \mathrm{IU} / \mathrm{mL}$ \\
\hline $\begin{array}{l}\text { Bone marrow } \\
\text { examination } \\
\text { and biopsy }\end{array}$ & Aplastic anemia & $\begin{array}{l}\text { Aplastic } \\
\text { anemia }\end{array}$ & Aplastic anemia & Not done & Aplastic anemia & Aplastic anemia \\
\hline
\end{tabular}

$N A$, not available; IgA, gamma A immunoglobulin; IgA -tTG, gamma A immunoglobulin tissue transglutaminase; Gl, gastrointestinal; IU/ml, International units per millilitre 
been reported from India or Pakistan as evident from Table 2. However, it is not possible to make a final statement linking the two on the data we have to date. This is why we believe there need to be larger studies to further explore this potential association.

\section{Abbreviations \\ AA: Aplastic anemia; CD: Celiac disease}

\section{Acknowledgements}

No acknowledgements to disclose.

\section{Funding}

There is no funding to disclose.

Availability of data and materials

Not applicable as patients information was held by the hospital.

\section{Authors' contributions}

OI was involved in literature search of topic, medical record review, introduction design draft, critical revision and interpretation of data, and final approval and agreement. SM was involved in discussion design, medical record review, critical revision and review, and final approval and agreement. HN was part of the primary team of pediatrics and involved in critical revision and editing of final manuscript, and final approval and agreement. GB was the primary pediatrician of the patient and involved in formatting, revision, concept and editing of final manuscript plus final approval and agreement. All authors fulfill the criteria and have contributed immensely to the final production of this manuscript. All authors read and approved the final manuscript.

\section{Ethics approval and consent to participate}

We have written consent from the Department of Pediatrics and Child Health, Aga Khan University to use this patient's information.

\section{Consent for publication}

Written informed consent was obtained from the patient's legal guardian for publication of this case report. A copy of the written consent is available for review by the Editor-in-Chief of this journal.

\section{Competing interests}

The authors declare that they have no competing interests.

\section{Publisher's Note}

Springer Nature remains neutral with regard to jurisdictional claims in published maps and institutional affiliations.

\section{Author details}

${ }^{1}$ Medical College, Aga Khan University Hospital, Karachi, Pakistan.

${ }^{2}$ Department of Pediatrics, Aga Khan University Hospital, Karachi, Pakistan.

Received: 24 June 2017 Accepted: 26 November 2017

Published online: 23 January 2018

\section{References}

1. Green PH, Cellier C. Celiac disease. N Engl J Med. 2007;357(17):1731-43. Epub 2007/10/26. eng.

2. Halfdanarson TR, Litzow MR, Murray JA. Hematologic manifestations of celiac disease. Blood. 2007;109(2):412-21. Pubmed Central PMCID: PMC1785098, Epub 2006/09/16. eng.

3. Grey-Davies E, Hows JM, Marsh JC. Aplastic anaemia in association with coeliac disease: a series of three cases. Br J Haematol. 2008;143(2):258-60. Epub 2008/08/14. eng.

4. Cosnes J, Cellier C, Viola S, Colombel JF, Michaud L, Sarles J, et al. Incidence of autoimmune diseases in celiac disease: protective effect of the glutenfree diet. Clin Gastroenterol Hepatol. 2008;6(7):753-8. Epub 2008/02/08. eng.

5. Badyal RK, Sachdeva MU, Varma N, Thapa BR. A rare association of celiac disease and aplastic anemia: case report of a child and review of literature. Pediatr Dev Pathol. 2014;17(6):470-3. Epub 2014/07/31. eng.
6. Baydoun A, Maakaron JE, Halawi H, Abou Rahal J, Taher AT. Hematological manifestations of celiac disease. Scand J Gastroenterol. 2012;47(12):1401-11. Epub 2012/08/07. eng.

7. Hernandez L, Green PH. Extraintestinal manifestations of celiac disease. Curr Gastroenterol Rep. 2006;8(5):383-9. Epub 2006/09/14. eng.

8. Maheshwari A, Nirupam N, Aneja S, Meena R, Chandra J, Kumar P. Association of celiac disease with aplastic anemia. Indian J Pediatr. 2012; 79(10):1372-3. Epub 2011/10/12. eng.

9. Kumar Suresh SR, Thapa BR. Celiac Disease Presenting As Pancytopenia. JK Sci J Med Educ Res. 2013;15(1):34-5.

10. Basu A, Ray Y, Bowmik P, Rahman M, Dikshit N, Goswami RP. Rare association of coeliac disease with aplastic anaemia: report of a case from India. Indian J Hematol Blood Transfus. 2014;30 Suppl 1:208-11. Pubmed Central PMCID: PMC4192180, Epub 2014/10/22. eng.

11. Hoekstra JH, Groot-Loonen JJ, van der Weij A, Hoogerbrugge PM, Kooy Y, Koning F. Successful treatment of coeliac disease by allogeneic haematopoietic stem cell transplantation. J Pediatr Gastroenterol Nutr. 2010; 51(6):793-4. Epub 2010/10/05. eng.

12. Salmeron G, Patey N, de Latour RP, Raffoux E, Gluckman E, Brousse N, et al. Coeliac disease and aplastic anaemia: a specific entity? Br J Haematol. 2009; 146(1):122-4. Epub 2009/05/15. eng.
Submit your next manuscript to BioMed Central and we will help you at every step:

- We accept pre-submission inquiries

- Our selector tool helps you to find the most relevant journal

- We provide round the clock customer support

- Convenient online submission

- Thorough peer review

- Inclusion in PubMed and all major indexing services

- Maximum visibility for your research

Submit your manuscript at www.biomedcentral.com/submit
C Biomed Central 